\title{
Genetic diversity and conservation of native populations of Maytenus Ilicifolia Mart. ex Reiss
}

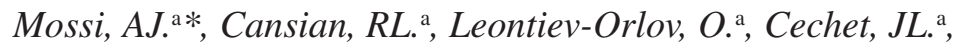 \\ Carvalho, AZ. ${ }^{\text {a }, T o n i a z z o, ~}$. $^{\text {a }}$ and Echeverrigaray, $S .{ }^{\text {b }}$ \\ aDepartamento de Ciências Agrárias, Campus de Erechim, \\ Universidade Regional Integrada do Alto Uruguai e das Missões - URI, \\ Av. 7 de setembro, 1621, CEP 99700-000, Erechim, RS, Brazil \\ bInstituto de Biotecnologia, Universidade de Caxias do Sul - UCS, \\ Av. Francisco Getúlio Vargas, 1130, CEP 95070-560, Caxias do Sul, RS, Brazil \\ Received February 27, 2008 - Accepted May 20, 2008 - Distributed May 31, 2009 \\ *e-mail: amossi@uricer.edu.br \\ (With 5 figures)
}

\begin{abstract}
The aim of this work was to analyze genetic variability in 18 populations of Maytenus ilicifolia, and representatives of Maytenus aquifolia and Maytenus evonymoidis, collected in the states of Mato Grosso do Sul, Paraná, Santa Catarina and Rio Grande do Sul, using RAPD molecular markers. Considering total samples of the three species, 263 amplified fragments were identified, of which $72.2 \%$ showed to be polymorphous. The index of similarity (Jaccard coefficient) was on average 0.64 between $M$. ilicifolia and $M$. aquifolia; 0.47 between M. ilicifolia and M. evonymoidis; and 0.44 between $M$. aquifolia and M. evonymoidis. The analysis of groupings by the UPGMA algorithm allowed to clearly separate the three analyzed species. In determining the variability in M. ilicifolia, 222 bands were identified, on average 11.1 bands per primer, being $43.2 \%$ polymorphous. The index of similarity (Jaccard coefficient) in the bulks of each population in M. ilicifolia was, on average, 0.92 and the index of similarities among the populations was 0.83 . The analysis of groupings with the UPGMA algorithm and the analysis of the main coordination (PCO), allowed the separation of the analyzed populations into three groups, the populations from the south of Rio Grande do Sul and the population from Mato Grosso do Sul standing out. A relation between the groupings found and the edaphoclimatic conditions of the collecting places was observed.
\end{abstract}

Keywords: conservation genetics, Espinheira Santa, native populations, molecular markers.

\section{Diversidade genética de conservação em populações nativas de Maytenus ilicifolia Mart. ex Reiss}

\begin{abstract}
Resumo
O objetivo deste trabalho foi analisar a variabilidade genética em dezoito populações de Maytenus ilicifolia, e representantes de Maytenus aquifolia e Maytenus evonymoidis, coletadas nos Estados do Mato Grosso do Sul, Paraná, Santa Catarina e Rio Grande do Sul, utilizando marcadores moleculares RAPD. Considerados todos os representantes das três espécies, foram identificados 263 fragmentos amplificados, dos quais 72,2\% mostraram-se polimórficos. O índice de similaridade (coeficiente de Jaccard) foi em média de 0,64 entre M. ilicifolia e M. aquifolia, de 0,47 entre M. ilicifolia e M. evonymoidis e de 0,44 entre $M$. aquifolia e M. evonymoidis. A análise de agrupamentos através do algoritmo UPGMA permitiu separar claramente as três espécies analisadas. Na determinação da variabilidade dentro de $M$. ilicifolia foram identificadas 222 bandas, em média de 11,1 bandas por primer, sendo 43,2\% polimórficas. O índice de similaridade (coeficiente de Jaccard) dentro dos bulks de cada população em M. ilicifolia foi em média de 0,92, e índices de similaridade entre as populações de 0,83. A análise de agrupamentos através do algoritmo UPGMA e análise de coordenadas principais (PCO), permitiram separar as populações analisadas em três grupos, destacando as populações do sul do RS e a de MS das outras avaliadas. Foi observada uma relação entre os agrupamentos encontrados e as características edafoclimáticas dos locais de coleta.
\end{abstract}

Palavras-chave: conservação genética, Espinheira Santa, populações naturais, marcadores moleculares. 


\section{Introduction}

The use of medicinal plants in Brazil is intense, especially by populations of a lower income, since Brazilian flora displays great biodiversity. However, scant knowledge and the bad use of natural resources have led to the loss of populations, and several medicinal plants are included in the list of species threatened with extinction. The genus Maytenus belongs to the Celastraceae family, and several of its species are used in popular medicine in different regions of the world. The great use of Maytenus ilicifolia Mart. ex Reiss 1861 has increased the degradation of this species, and thus it is presently included in FAO's list for priority species for studying and conservation in South America. In this context, this work aimed to contribute with studies that help towards the conservation of this species.

In Brazil, the species Maytenus aquifolia Mart. 1841 and Maytenus ilicifolia are popularly used as anti-spasmodic, contraceptive, anti-ulcerous, diuretic, cicatrizing, and analgesic features. Studies performed with animals in the laboratory (Oliveira et al., 1991; Souza-Formigoni et al., 1991) proved the anti-ulcerous effect of $M$. aquifolia and M. ilicifolia, which was attributed to the increasing of volume and $\mathrm{pH}$ of the gastric juices (Souza-Formigoni et al., 1991), and their activities as an anti-oxidant (Vellosa et al., 2006), and anti septic and cicatrizing effects (Carlini and Braz, 1998). Several compounds are presented in the extract, such as phenols, tannins and terpenes (Camparoto et al., 2002).

Carvalho-Okano (1992) identified the southwest region as the primary centre of specific diversity of Maytenus in Brazil, because it houses the biggest number of species. However, the current geographical distribution of M. ilicifolia occurs principally in the southern region of Brazil (Paraná, Santa Catarina and Rio Grande do Sul), being preferably found in the sub-woods or the margins of rivers. The author also mentions the fact that she did not find material in herbariums in São Paulo and Mato Grosso do Sul, where the occurrence would be rare.

The low frequency of occurrence, the intense use in phitotherapy by the population and the big anthropic action in the region of natural occurrence of this species has taken it to degrading. In this sense, genetic studies are fundamental for the handling and conservation of this species.

The use of molecular markers is a powerful tool in the genetic study of populations, RAPD (Random Amplifies Polymorphic DNA) being suitable for the analysis of genetic diversity in natural populations of allogamous species (Ferreira and Grattapaglia, 1998). Few studies on genetic and chemical diversity have been performed in M. ilicifolia so far. Bittencourt (2000) studied the genetic variability of two populations of M. ilicifolia in the state of Paraná, using RAPD molecular markers, and Perecin (2002), using biochemical markers (allozymes), studied genetic diversity in five populations of $M$. aquifolia in the state of São Paulo and one population of M. ilicifolia in Santa Catarina.

The objective of the present work was to analyze genetic variability in 18 native populations of $M$. ilicifolia distributed in the south and mid-west regions of Brazil (Mato Grosso do Sul, Paraná, Santa Catarina and Rio Grande do Sul), using RAPD molecular markers, aiming to contribute for determining strategies for the species' conservation.

\section{Material and Methods}

Plants of the eighteen native populations of espinheira santa $(M$. ilicifolia) were sampled in three Brazilian states: Mato Grosso do Sul, in the town of Ponta Porã; Paraná, in the towns of Lapa, Irati, Guarapuava and Mangueirinha; Santa Catarina, in the towns of Lages, São Joaquim and Caçador; and Rio Grande do Sul, in the towns of Santana do Livramento, Canguçu, Unistalda, Vale Verde, Soledade, Flores da Cunha, Bom Jesus, Erechim, Barão de Cotegipe and São José (Figure 1). The group of plants geographically isolated was considered as a population. Thirty adult plants collected randomly in each area represented each population, forming 3 bulks of 10 individuals for each population. The minimum distance between two plants was $10 \mathrm{~m}$. Besides genetic analysis in $M$. ilicifolia populations, $M$. aquifolia and Maytenus evonymoides Reissek were used for interspecific comparison.

The sample regions were based on Koppen's classification, based on environmental characteristics (latitude, longitude, vegetation, annual average temperature, climate, geomorphology, and types of soil).

\subsection{Genetic analysis}

The leaves collected in each plant were immediately placed in liquid nitrogen, and then stored in a freezer at $-80{ }^{\circ} \mathrm{C}$ until DNA extraction, which occurred with the formation of three bulks with 10 plants per population.

For the isolation of total DNA, the method described by Doyle and Doyle (1987), modified for the use of M. ilicifolia (Bittencourt, 2000) was used. The basic process consists of: maceration of about $150 \mathrm{mg}$ of leaves in liquid nitrogen; addition of $750 \mu \mathrm{L}$ of extraction buffer (2\% CTAB, $1.4 \mathrm{M} \mathrm{NaCl}, 20 \mathrm{mM}$ EDTA, $100 \mathrm{mM}$ Tris- $\mathrm{HCl} \mathrm{pH}$ 8.0, 0.2\% 2-Mercaptoetanol, $0.01 \%$ Proteinase $\mathrm{K}, 1 \% \mathrm{PVP}$ ); maintenance in immersion for 45 minutes at $65{ }^{\circ} \mathrm{C}$; removing residual protein with one volume of $24: 1$ chloroform: isoamyl alcohol until total cleaning of DNA; precipitation with 2/3 volume of isopropanol and two washings with $1000 \mu \mathrm{L}$ ethanol $70 \%$; re-suspension in $150 \mu \mathrm{L}$ of TE (Trisma: EDTA 10:1); quantification in UV spectrophometry at $260 \mathrm{~nm}$ and confirmation of integrity and purity in spectrophometry UV at $280 \mathrm{~nm}$ and in $0.8 \%$ agarose gel.

The reactions of RAPD amplifications were performed according to Williams et al. (1990), with some modifications. In a total volume of $25 \mu \mathrm{L}$ : reaction buffer 


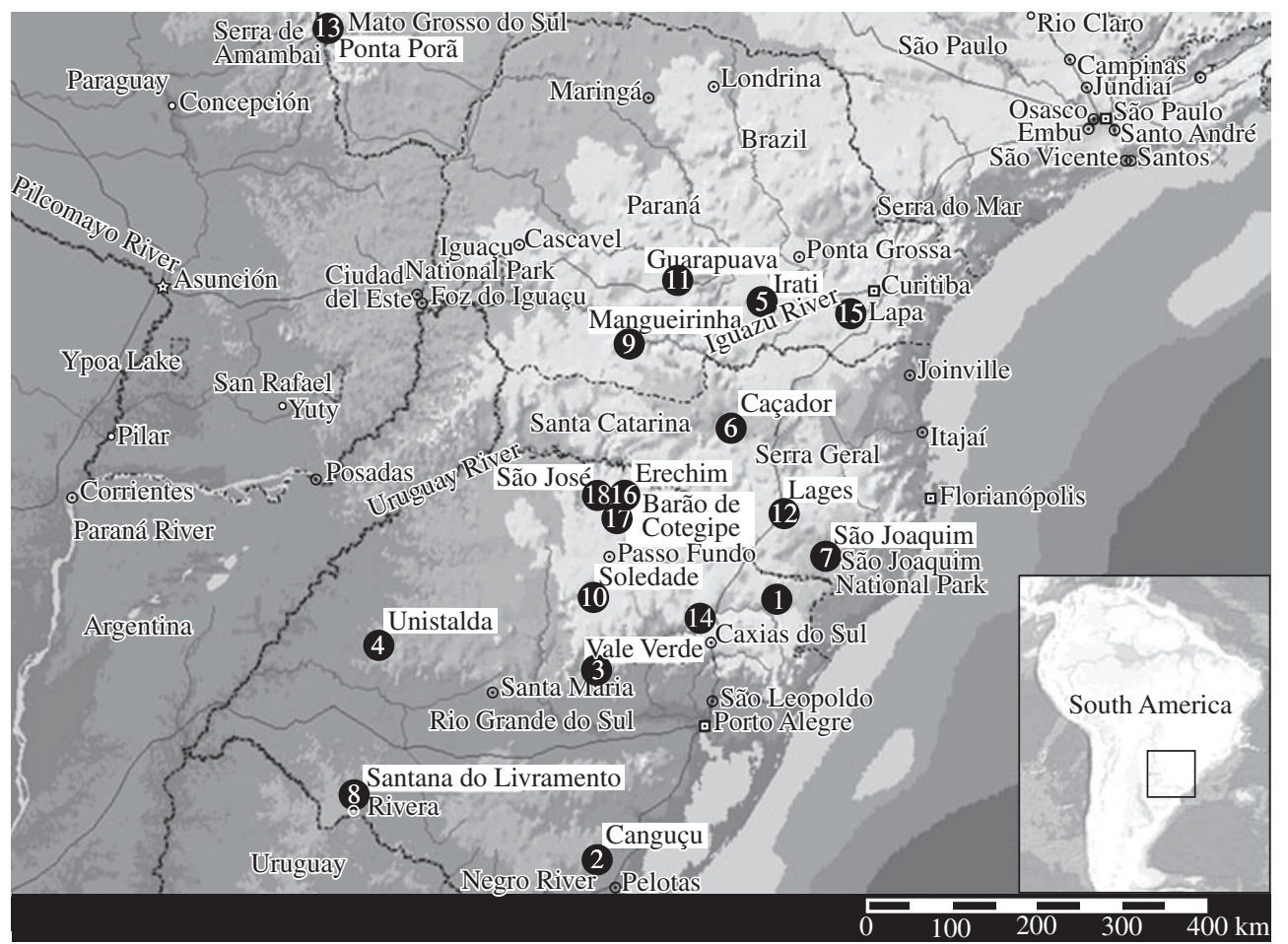

Figure 1. Collecting places of the 18 populations of M. ilicifolia in the states of Mato Grosso do Sul, Santa Catarina, Paraná and Rio Grande do Sul, Brazil.

(50 mM Tris- $\mathrm{HCl} \mathrm{pH} 9.0 ; 50 \mathrm{mM} \mathrm{KCl})$, dNTPs (200 mM of each), $0.2 \mathrm{mM}$ of primer, $3 \mathrm{mM}$ of $\mathrm{MgCl}_{2}, 0.25 \mathrm{mM}$ of TRITON and 1.5 U of Taq DNA polimerase Gibco BRL (Life Technologies, São Paulo, Brazil) and 40-50 ng of DNA.

For the selection of the primers, kits OPA, OPB, OPD, OPF, OPH, OPW, and OPY from Operon Technologies, containing 20 primers each were used, aiming to identify those which presented better results for M. ilicifolia, evaluating the quantity of bands produced, their intensities, their repetition and the polymorphism generated by them.

The amplification was performed in thermocycler (model PTC 100, MJ Research INC., Watertown, MA). The process of amplification was based on the following sequence: 3 minutes at $92{ }^{\circ} \mathrm{C}$ and 40 cycles of 1 minute at $92{ }^{\circ} \mathrm{C}, 1$ minute at $35^{\circ} \mathrm{C}$ and 2 minutes at $72{ }^{\circ} \mathrm{C}$. Then, 3 minutes at $72{ }^{\circ} \mathrm{C}$ and cooling at $4{ }^{\circ} \mathrm{C}$ until the retreat of the samples.

Electrophoretic separation was performed in agarose gel $1.4 \%$ in buffer TBE IX (0.089 M Trisma, $0.089 \mathrm{M}$ Boric Acid and 0.008 M EDTA) in horizontal electrophoresis, and a potential of $90 \mathrm{~V}$. DNA Ladder $100 \mathrm{bp}$ from Gibco (BRL) was used as a molecular weight marker. The visualization of fragments was done with ethidium bromide and the observation was performed using UV light. The gels were photographed using the digital CEL-PRO System (Media Cybernetics, Silver Spring, MD). For each primer analyzed, three gels con- taining a bulk of each population of M. ilicifolia were prepared together with one representative from the other two species.

The data analysis was performed as following: in determining genetic variability, the data obtained through the determination of presence or absence of bands formed a matrix, which was analyzed with the help of a statistic pack (MVSP). The dendograms were built by algorithm UPGMA (Unweighted Pair Group Method Using Arithmetic Averages), developed by Sokal and Michener (1958) using Jaccard coefficient of similarity. Confidence limits for groupings were calculated by randoming 100 samples of the results using the Winboot program (Yap and Nelson, 1996). The analysis of the main intra and inter-specific coordination was analyzed by MVSP (Multi-Variate Statiltical Package 3.1, Kovach Computing Service).

\section{Results and Discussion}

In the study of variability, 20 primers from Operon Technologies (Table 1) were used. The primers used were selected from 140 decanumeric primers from kits OPA, OPB, OPD, OPF, OPH, OPW and OPY. The selection of primers was based on quantity, intensity and repetition of amplified fragments and results obtained by Bittencourt (2000). Considering that the amplification of fragments can be affected by factors such as concentration of reaction components and different conditions 
Table 1. Total number and number of polymorphic fragments obtained in each primer used in the three populations analyzed.

\begin{tabular}{|c|c|c|c|c|c|c|c|c|}
\hline \multirow[t]{2}{*}{ Primer } & \multirow{2}{*}{$\begin{array}{l}\text { Sequence } \\
\left(5^{\prime} \text { to 3') }\right.\end{array}$} & \multicolumn{4}{|c|}{ Total fragments } & \multicolumn{3}{|c|}{ Specific fragments } \\
\hline & & M. ilic & M. aqui & M. evon & Poli & M. ilic & M. aqui & M. evon \\
\hline OPA-04 & CAGGCCCTTC & 12 & 6 & 8 & 12 & 1 & 1 & - \\
\hline OPA-08 & GTGACGTAGG & 8 & 6 & 6 & 11 & 3 & 1 & 3 \\
\hline OPA-09 & GGGTAACGCC & 9 & 5 & 4 & 8 & 3 & - & 1 \\
\hline OPA-11 & CAATCGCCGT & 16 & 11 & 10 & 11 & 4 & - & 1 \\
\hline OPA-19 & CAAACGTCGG & 9 & 4 & 8 & 9 & 3 & 1 & 2 \\
\hline OPB-07 & GGTGACGCAG & 13 & 9 & 9 & 12 & 3 & 1 & 2 \\
\hline OPB-11 & GTAGACCCGT & 15 & 9 & 10 & 14 & 4 & - & 1 \\
\hline OPB-12 & CCTTGACGCA & 8 & 4 & 7 & 10 & 1 & 1 & 2 \\
\hline OPB-13 & TTCCCCCGCT & 6 & 4 & 2 & 4 & 1 & - & - \\
\hline OPD-20 & ACCCGGTCAC & 13 & 10 & 11 & 9 & 2 & - & 1 \\
\hline OPD-08 & GTGTTGCCCA & 13 & 13 & 9 & 8 & 2 & - & - \\
\hline OPF-01 & ACGGATCCTG & 16 & 9 & 10 & 13 & 6 & 2 & 1 \\
\hline OPF-10 & GGAAGCTTGG & 11 & 10 & 8 & 11 & 1 & - & 4 \\
\hline OPH-03 & AGACGTCCAC & 12 & 9 & 9 & 7 & 2 & - & 2 \\
\hline OPW-08 & GACTGCCTCT & 8 & 6 & 6 & 6 & 3 & 1 & 1 \\
\hline OPW-16 & CAGCCTACCA & 9 & 7 & 5 & 12 & 2 & - & 4 \\
\hline OPY-08 & AGGCAGAGCA & 9 & 7 & 7 & 8 & 2 & 1 & 2 \\
\hline OPY-10 & CAAACGTGGG & 9 & 4 & 6 & 7 & 2 & - & - \\
\hline OPY-13 & GGGTCTCGGT & 13 & 8 & 12 & 7 & 1 & - & - \\
\hline OPY-18 & GTGGAGTCAG & 13 & 10 & 8 & 11 & 3 & - & 2 \\
\hline \multicolumn{2}{|r|}{ Total } & 222 & 158 & 155 & 190 & 49 & 9 & 27 \\
\hline
\end{tabular}

of amplification cycles (Geburek, 1997), only amplified fragments that presented a high intensity and reproduction in three repetitions of amplification were considered for the evaluation.

In the analysis of the bulks representative of each of the 18 populations of $M$. ilicifolia, M. aquifolia and $M$. evonymoidis, 263 fragments were considered, being $190(72.2 \%)$ polymorphics and 73 (27.8\%) monomorphics. The amplified fragments presented between 100 and $2200 \mathrm{bp}$. The average number of fragments per primer was 13.15 , and this result was found to be superior to the one found in the intra-population analysis in M. ilicifolia of 10.9 (Mossi et al., 2007). This difference can be attributed to the presence of $41(15.6 \%)$ bands from $M$. aquifolia and $M$. evonymoidis. The average number of bands obtained per primer is superior to the one found by Bittencourt (2000) in M. ilicifolia, which was 7.42 per primer. This difference can be attributed to distinct laboratorial conditions, to the primers used, and to the rigidity established in the choice of fragments for analysis.

Regarding the presence or absence of bands in the species, from the 263 bands analyzed, 49 bands (18.6\%) were observed to occur only in M. ilicifolia, nine bands (3.4\%) in M. aquifolia and 27 (10.3\%) in M. evonymoidis. M. ilicifolia and $M$. aquifolia are both widely used in popular medicine, and they are often confused due to their morphologic similarities (Carvalho-Okano, 1992).
The low number of specific bands for $M$. aquifolia confirms this proximity, but it also brings the possibility of using molecular markers in the identification of mixtures and adulteration.

The index of similarity (Jaccard coefficient) between M. ilicifolia and M. aquifolia varied between 0.59 and 0.69 with average of 0.64 , between $M$. ilicifolia and $M$. evonymoidis it was from 0.43 to 0.50 with an average of 0.47 , and between $M$. aquifolia and M. Evonymoidis it was on average 0.44 . As expected, the indices of similarities between the species were inferior in comparison to the ones within the species (0.72 to 0.79) (Mossi et al., 2007).

The analysis of groupings by means of the UPGMA algorithm (Figure 2) allowed to clearly separate the species analyzed with $100 \%$ of confidence, being M. evenymoidis the most distant one. The high presence of sharing fragments between M. ilicifolia and M. aquifolia indicates a high relationship between the species. In the same way, Perecin and Kageyama (2002), in studies with allozymes loci, verified the presence of many alleles shared between M. ilicifolia and M. aquifolia, and the authors suggest the possibility that the species are not completely isolated reproductively or that this fact occurred in a not very distant space of time.

In M. ilicifolia, 222 bands from 20 primers, which originated, on average, 11.1 bands per primer were analyzed. From this total, 126 (56.8\%) were monomorphics 


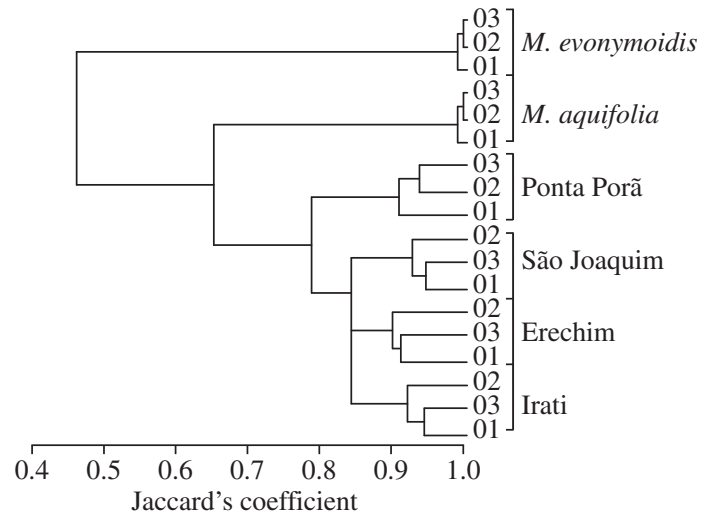

Figure 2. Dendogram of some populations of $M$. ilicifolia and the species $M$. aquifolia and $M$. evonymoidis determined by RAPD, using Jaccard's coefficient and UPGMA grouping. and $96(43.2 \%)$ polimorphics. The level of polimorphism was lower than that observed by Mossi et al. (2007), who evaluated the intra and inter population genetic variability of M. ilicifolia. In this study a polymorphism of $71.5 \%$ was observed.

The index of similarity (Jaccard coefficient) inside the bulks of each population in M. ilicifolia varied between 0.87 and 0.96 with an average of 0.92 and the indices of similarity between populations varied from 0.83 to 0.91 with an average of 0.83 .

The analysis of grouping using the UPGMA algorithm (Figure 3) allowed the characterization of each population, since the internal bulks remained next, grouping themselves with indices of average confidence of $88 \%$. Group I was formed of a population derived from Ponta Porã (MS), group II by populations from Santana do Livramento, Vale Verde, Canguçu and Unistalda, all

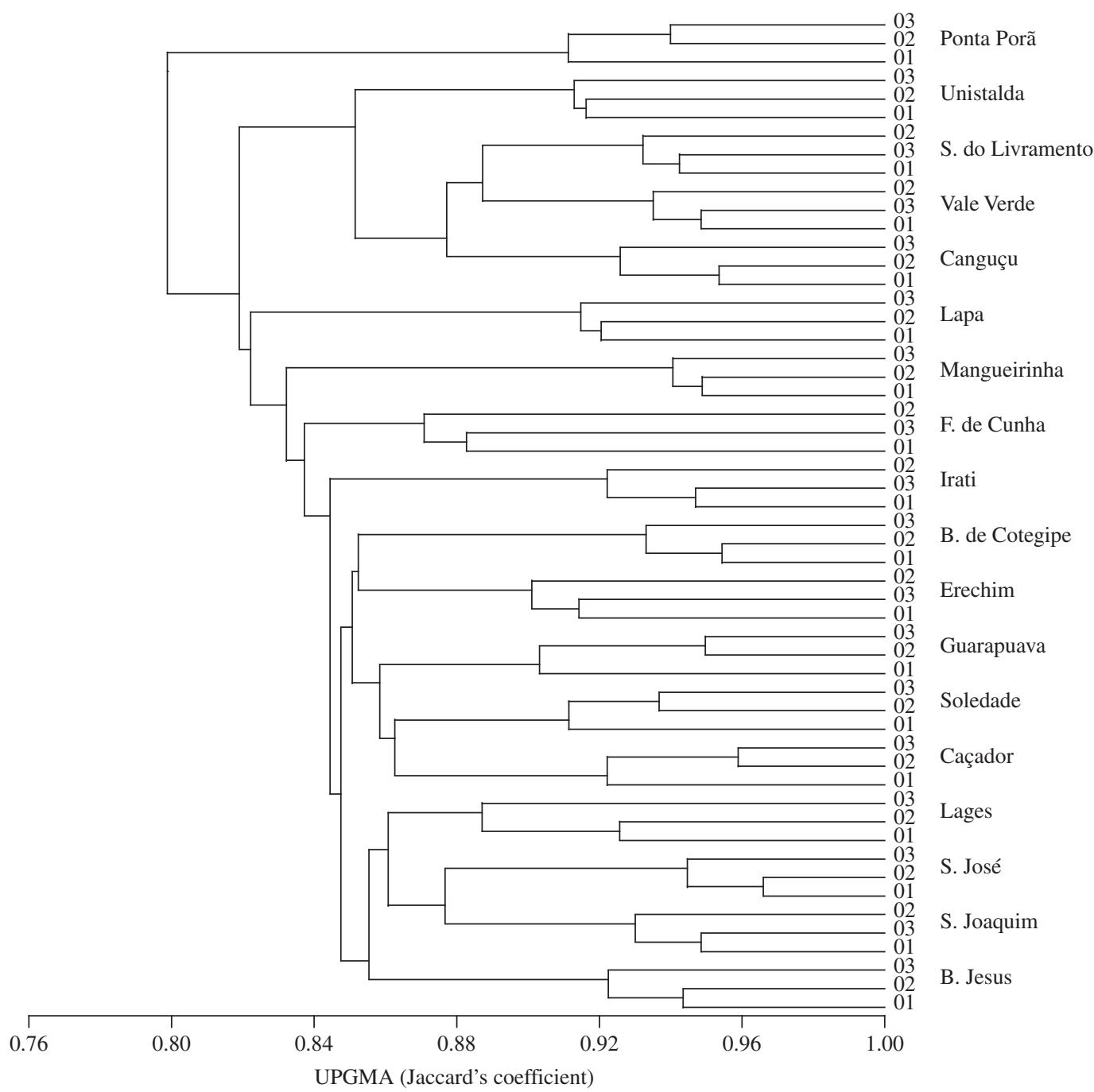

Figure 3. Dendrogram based on the analysis of grouping (UPGMA) of genetic similarity estimation (Jaccard's coefficient) by RAPD in M. ilicifolia populations. 
of them from the southern region of Rio Grande do Sul, and group III by the thirteen remaining populations. The separation of these three groups was confirmed by the analysis of the main coordinators (PCO), using Euclidian distances (Figure 4) in which a tendency of separation between Ponta Porã's population and populations from the southern region of Rio Grande do Sul is observed.

Figure 5 shows the comparison of the groupings obtained by the analysis of molecular markers and the groupings of the regions where the plants were sampled based on Koppen's classification. It may be noted that the group separation corresponds to different environments.

The high similarities among populations and the low definition of the groups corroborate with the results obtained by Bittencourt (2000). This might be related to

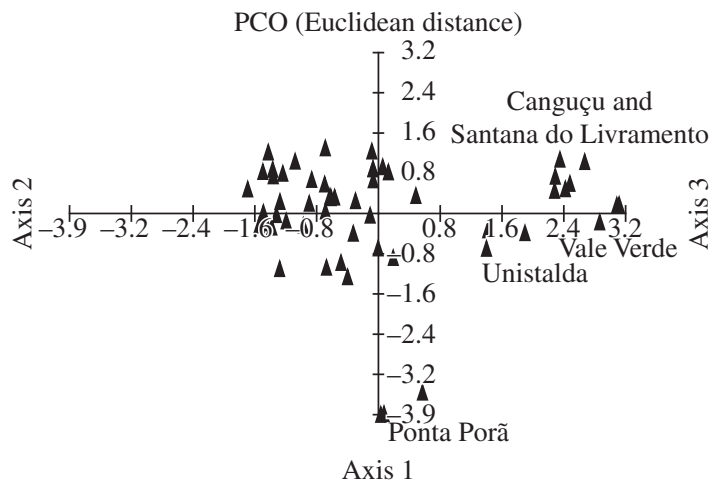

Figure 4. Analysis of Main Coordination by Euclidian distance of the 18 populations of M. ilicifolia analyzed. the fact that the southwest region is the primary centre of specific diversity of Maytenus sp., and that M. ilicifolia occurs preferably in the sub-woods of Araucaria Forest and on the margins of rivers (Carvalho-Okano, 1992), and in the arboreal groupings in regions of steppes. The Araucaria forest has a recent origin (2,500 to 4,000 years) in the southern region of Brazil (Joly et al., 1999), and thus it has a recent occurrence of species related to it.

Despite the genetic proximity, one can notice a tendency of distance and isolation of Ponta Porã's population, possibly influenced by a founder effect and kept by its relative isolation from the other regions of occurrence of the species. In the southern region, there is also a tendency of grouping and distancing of Santana do Livramento, Canguçu, Unistalda and Vila Verde's populations, possibly due to the pressure of selection associated to climatic differences and vegetation. Considering the dispersion centre of the species, the southern region corresponds to a marginal area of distribution, with occupation of new environments, which normally brings about variation of allelic frequencies.

The results allowed us to conclude that RAPD molecular markers are effective in the differentiation of the studied species (M. ilicifolia, M. aquifolia and $M$. evonymoidis) and in the study of genetic variability in M. ilicifolia.

The molecular markers showed a high genetic similarity in M. ilicifolia's populations. However, they also allowed the separation of populations in groups of similarity, which are related to the distinct environments of occurrence of M. ilicifolia (Southern Brazil, Araucaria forest and the mountain ridges of Mato Grosso do Sul).

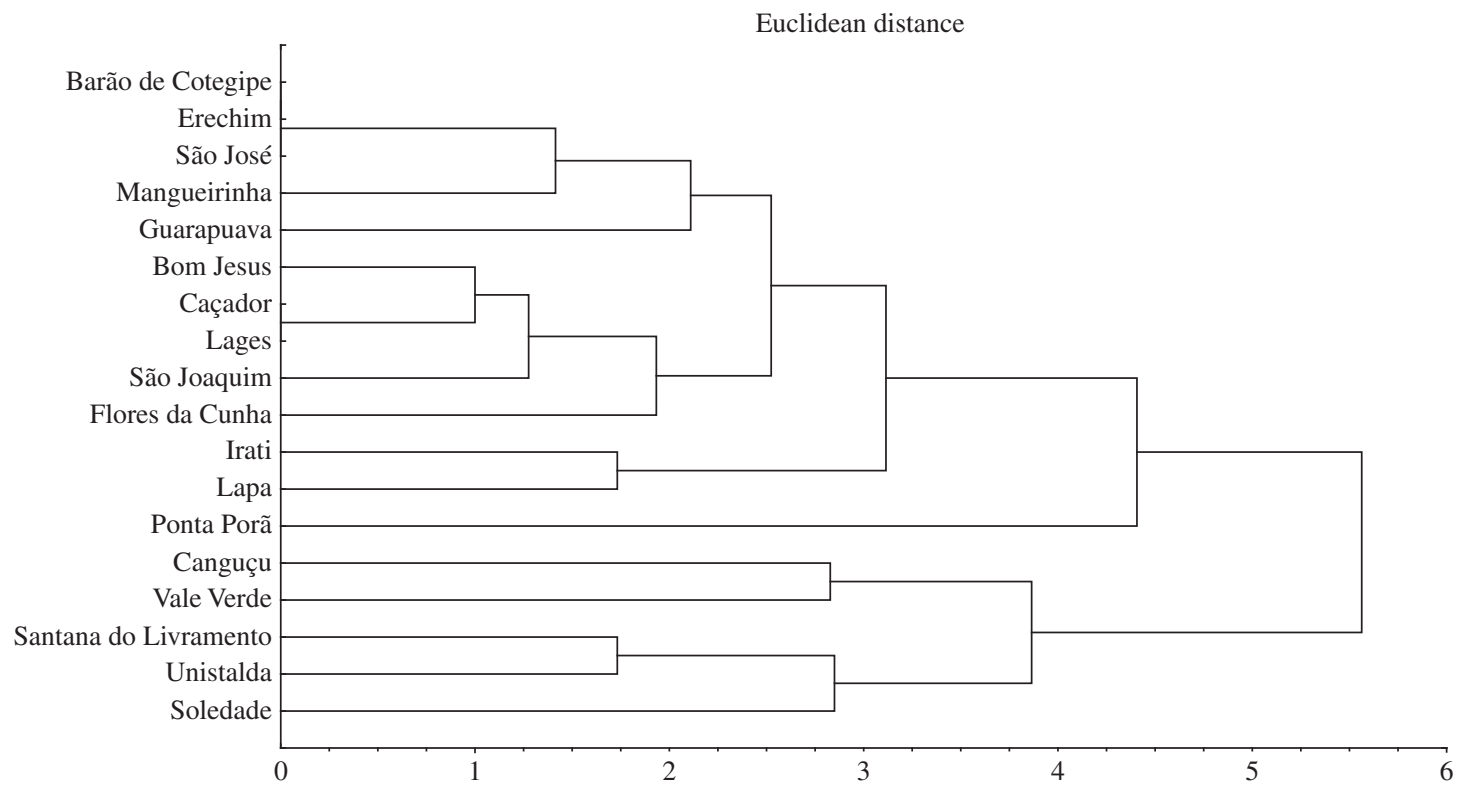

Figure 5. UPGMA grouping with Euclidian distances of the 18 populations analyzed, based on environmental characteristics of each place (latitude, longitude, altitude, annual average temperature, vegetation, Koppen climatic classification, geomorphology and kinds of soil). 
This study suggests that the formation of three distinct groups in Brazil is occurring possibly due to the influence of evolutionary forces, since the groups are separating themselves according to environmental conditions (Koppen's classification).

However, in the last 50 years, a great anthropogenic impact is occurring in these regions, with intense fragmentation that caused the loss of populations and the consequent isolation of the remaining ones.

In species that become fragmented into small populations and isolated subpopulations, the random change in gene frequencies (genetic drift) and the mating of related individuals (biperental inbreeding) have driven species to the brink of extinction (Geburek, 1997). The challenge now is to develop good conservation programs and to put them into action. Romeiras et al. (2007) concluded that the actions for conservation of Echium stenosiphon should be based on the genetic diversity of the groups identified in the population. In the same way, we can propose that the conservation programs of M. ilicifolia must consider the genetic variability of the three distinct groups detected by RAPD analysis.

Acknowledgements - The authors thank CNPq, SCT-RS, and FAPERGS for the financial support, and EMATER/RS and EMBRAPA/Florestas for technical assistance.

\section{References}

BITTENCOURT, JVM., 2000. Variabilidade genética em populações naturais de maytenus ilicifolia por meio de marcadores RAPD. Curitiba: Universidade Federal do Paraná. 58p. Dissertação de Mestrado.

CAMPAROTO, ML., TEIXEIRA, RO. and MANTOVANI, MS., 2002. Effects of Maytenus ilicifolia Mart. and Bauhinia candicans Benth infusions on onion root-tip and rat bonemarrow cell. Genetics and Molecular Biology, vol. 25, no. 1, p. $85-89$.

CARLINI, EA. and BRAZ, S., 1998. Efeito protetor do liofilizado obtido do abafado de Maytenus sp. (Espinheira-Santa) contra úlcera gástrica experimental em ratos. In CARLINI, E.A. (Eds.). Estudo da ação antiúlcera gástrica de plantas brasileiras. Brasília: Central de Medicamentos - CEME/AFIP. p. 21-35.

CARVALHO-OKANO, RM., 1992. Estudos taxonômicos do gênero Maytenus MOL. emend. Mol. (Celastraceae) do Brasil Extra-amazônico. Campinas: Universidade Estadual de Campinas. 252p. Tese de Doutorado.

DOYLE, JJ. and DOYLE, JL., 1987. A rapid DNA isolation method for small quantities of fresh tissues. Phytochemical Buletin, vol. 19, p. 11-15.
FERREIRA, EM. and GRATTAPAGLIA D., 1998. Introdução ao uso de marcadores moleculares em análise genética. Brasília: EMBRAPA; CENARGEN.

GEBUREK, T., 1997. Isozymes and DNA markers in gene conservation of forest trees. Biodiversity and Conservation, vol. 6 , no. 12 , p. 1639-1654.

JOLY, CA., AIDAR, MPM., KLINK, CA., McGRATH, DG., MOREIRA,AG., MOUTINHO,P.,NEPSTAD, DC., OLIVEIRA, AA., POTT, A., RODAL, MJN. and SAMPAIO, EVSB., 1999. Evolution of the Brazilian phytogeography classification systems: implications for biodiversity conservation. Ciência $e$ Cultura, vol. 51, no. 5-6, p. 331-348.

MOSSI, AJ., CANSIAN, RL., LEONTIEV-ORLOV, O., ZANIN, EM., OLIVEIRA, CH.; CECHET, ML., CARVALHO, AZ. and ECHEVERRIGARAY, S., 2007. Intra and inter populational genetic variability in Maytenus ilicifolia Mart. Ex Reiss, through RAPD Markers. Revista Brasileira de Biologia = Brazilian Journal of Biology, vol. 67, no. 4, p. 957-961.

OLIVEIRA, MGM., MONTEIRO, MG., MACAUBAS, C., BARBOSA, VP. and CARLINI, EA., 1991. Pharmacologic and toxicologic effects of two Maytenus species in laboratory animals. Journal of Ethnopharmacology, vol. 34, no. 1, p. $29-41$

PERECIN, MB. and KAGEYAMA, PY., 2002. Variabilidade isoenzimática em populações naturais de Espinheira-Santa Maytenus aquifolia Mart. e Maytenus ilicifolia Mart. ex Reiss e suas implicações para o manejo da conservação. Revista Brasileira Planta Médica, vol. 4, no. 2, p. 80-90.

ROMEIRAS, MR., COTRIM, HC., DUARTE MC. and PAIS, MS., 2007. Genetic diversity of three endangered species of Echium L. (Boraginaceae) endemic to Cape Verde Islands. Biodiversity and Conservation, vol. 16, no. 2, p. 547-566.

SOKAL, RR. and MICHENER, CD., 1958. A statistical method for evaluating systematic relationships. The University of Kansas Scientific Bulletin, vol. 38, p. 1409-1438.

SOUZA-FORMIGONI, ML., OLIVEIRA, MGM., MONTEIRO, MG., SILVEIRA-FILHO, NG., BRAZ, S. and CARLINI, EA., 1991. Antiulcerogenic effects of two Maytenus species in laboratory animals. Journal of Ethnopharmacology, vol. 34 , no. 1 , p. 21-27.

VELLOSA, JCR., KHALIL, NM., FORMENTON, VAF., XIMENES, VF., FONSECA, LM., FURLAN, M., BRUNETTI, IL. and OLIVEIRA, OMMF., 2006. Antioxidant activity of Maytenus ilicifolia root bark. Fitorepia, vol. 77, no. 3, p. $243-244$.

WILLIAMS, JGK., KUBELIK, AR., LIVAK, KJ., RAFALSKI, LA. and TINGEY, SV., 1990. DNA polymorphisms amplified by arbitrary primers are useful as genetic markers. Nucleic acids research, vol. 18, no. 22, p. 6531-6535.

YAP, I. and NELSON, RJ., 1996. Winboot: a program for performing bootstrap analysis of bynary data to determine the confidence limits of UPGMA based dendograms. Manila: International Rice Research Institute. Discussion Paper Series $n^{\circ} 14$. 
